\title{
A Beginning from Dead End: Consolidating Achievements and Making Smooth Transition to Democracy in Ethiopia
}

\author{
Kena Deme Jebessa \\ Lecturer, College of Social Science and Humanities, Ambo University: Ethiopia
}

\begin{abstract}
Ethiopia has been experiencing extreme and repeated mass protests, uprising and society-government relationship crisis over the past two to three decades. The absolute dominance of a single vanguard party, EPRDF as well as the absence of fair representation of Ethiopian nations, nationalities and peoples at federal institutions resulted power dominance by single ethnic group, deterioration of institutions and political opposition. After many sacrificed their lives, new chapter is opened that new leadership came to the position of prime minister as a measure of how the EPRDF tried to convince Ethiopians that it is renewing itself. The new leadership started taking reforms. The reforms introduced by the new leadership were unthinkable not so long ago. However, as reforms started, different challenges are obstructing it. This study shows that the current Ethiopian condition requires going forward and strongly firm on securing rule of law and justice. Finally, if Ethiopia is going to be surviving as a state in the future, it highly demands encouraging the existing reform through institutionalizing hand in hand with democratic federalism; otherwise it is impossible to bring national unity and stability.
\end{abstract}

Keywords: Protest, Reform, Ethiopia, Transition to Democracy, Revolution in Ethiopia

DOI: $10.7176 / \mathrm{IAGS} / 74-04$

Publication date:July $31^{\text {st }} 2019$

\section{Introduction}

Ethiopia, a multi-ethnic and multi-linguistic state found in the horn of Africa is in a transition of reform now. A notable political and economic change in Ethiopia is a change from highly homogenization based on one nation and uniform linguistic principle and centrist rule to a federal system aiming at managing its complex diversity. Ethiopia is a multinational country that has multilevel layers of governments within its federal arrangement. Since the overthrow of the military regime in 1991, Ethiopia entered to a new era which is signified by the establishment of a federal state structure. A federal constitution of Ethiopia was proclaimed to establish the Federal Democratic Republic of Ethiopia (FDRE) in 1995 (Proc. No.1/1995), which vindicates parliamentary federal democracy with two chambers at the federal level and nine regional governments with one chamber each, except for the Southern Nations, Nationalities and Peoples State which later adopted a bicameral arrangement. This process of state transformation has completely abandoned the highly centralized government structure that had been practiced nearly for about a century. The post-1991 dispensation has ended years of civil war, and served as a foundation for the impressive economic performance. ${ }^{1}$ The recognition of Ethiopian ethno-linguistic diversity became the central principle of the existing regime policy. Lately the country has continued to face wide-spread protests. ${ }^{2}$

The top-down approach of the ruling-party, which is inspired by its hegemonic aspiration seriously, impeded the hoped for democratization process and the demand for shared-rule as well as self-rule across the country. ${ }^{3}$ This brought protest across Ethiopia. Ethiopia is rocked by prolonged waves of protest in the past two decades which was very extreme for the past three years. The outcome as witnessed in the protests is new mobilization and conflict unleashed.

However, the protest played a significant role in shaping the political landscape of the country that resulted in the resignation of the former prime minister and the coming of a new one. In the wake of the persistent insurrectionary activities by the Ethiopians, the new prime minister selected by an exhausted Ethiopian people's revolutionary democratic front to lead the party. A transitional period is the most momentous in a country's history. The new leadership promised to restore peace and stability in the country ${ }^{4}$ and was received by a very warm welcome from the public irrespective of political ideology, political affiliation and social status.

Apart from this, the new Ethiopian government has been able to destroy both psychological and physical

\footnotetext{
1 Keller, E., \& M. Omwami, E. Federalism, Citizenship, and National Identity in Ethiopia. The Journal of African Studies, 6(1), 37-69, 2007

2 An accumulation of years of frustration from ethnic groups who are marginalized by the government brought endless protests that finally lead to the coming to power of new leadership. Demonstrations began in Oromia and later sprung up in different parts of Ethiopia.

${ }^{3}$ A coalition of several ethnic groups that was controlled by the ethnic minority Tigray People's Liberation Front (TPLF), the EPRDF party has stunted political opposition by jailing dissidents, coercing citizens into joining the party and reportedly committing electoral fraud. Its regular elections thus have not shaken its widespread reputation as an authoritarian state.

${ }_{4}$ Following the handing over ceremony, the new prime minister delivered nationwide issues to the peoples of Ethiopia on April 02, 2018. His appointment marks a significant step towards resolving the unrest and violence that led to the decree of state of emergency repeatedly.
} 
walls around the Ethiopia and Eritrea border areas and built bridge of unity. The greater part of unity and inclusivity called 'medemer' political thought for the horn of Africa is on verge of being accomplished. Basically the objective of this study is to forward possible mechanisms that help to overcome the transitional reform challenges and consolidate achievements to make smooth transition to democracy in Ethiopia.

\section{Problems: Challenges of Transitional Reforms}

It was a new chapter of history for Ethiopian nations, nationalities and peoples to adopt federal system that helps local self-rule. This is so because it helps to encourage shared rule at the center through representation. However, there was no real political representation at the central level for the past two to almost three decades. At local level, self-rule of nation, nationalities and peoples is undermined because of the influence that comes from the center. ${ }^{1}$ This brought other new history that started to characterize Ethiopia by wide public protest. From all corners, Ethiopian's actively participated in the revolution which later brought the fall of the prime minister of one of Africa's most autocratic governments. The new Ethiopian government has redressed some of the wrongs committed by EPRDF ruling political party, brought peace with Eritrea and released political prisoners. The current government approach is summed up by philosophy of inclusivity and unity. The existing political, economical and social reforms have led millions to believe that positive revolutionary change is on its way. But there's one significant group that the new Ethiopian government has yet to address challenges which Ethiopian transition to democracy is facing. Earlier to struggles made by the new Ethiopian prime minister to transform Ethiopia in to real democracy, constitution on paper in to constitutionalism and promises into reality, varied clashes and instability erupted in different parts of the country. ${ }^{2}$ Clashes were witnessed in Hawassa, EthioSomali-Oromia, Welkite, Harari, Assosa, Gedeo and West Guji zones and more recently in the BenishangulGumuz national regional state-Oromia national regional state border. The crisis underlines a key challenge for new leadership that took power after mass protests sparked the predecessor's shock resignation. Even though there are contending views regarding the recent clashes in different parts of the country, it is a mere fact that people are suffering due to these clashes ${ }^{3}$. Some argues that there were so many questions in the past and eventually the questions got favorable ground to be enhanced. ${ }^{4}$ In addition to this, officials and individuals who are not happy with Ethiopian new administration effort to make smooth transition to democracy exist behind this conflict.

Now, the moment in Ethiopia is a transitional reform period. There are different challenges that the transitional period is facing which is not limited to ethnic conflicts of here and there only. There is a group who argues that the old regime itself is trying to make existing reform not to be successful. The old regime group collected from individuals who are well resourced and having huge resources inside and outside the country can possibly damages the ongoing reform. The objective of this group is to make sure that this transition isn't successful. This could be possible through creating enough problems in different parts of the country that will make the new leadership busy putting out fires rather than focusing on redistributive justice or holding them accountable. The other is they probably want to spread lawlessness and manipulate the economy, creating further chaos from which they can benefited. It is clear that the reform idea ultimately is to rock the ruling party without in fact dividing it. There are forces standing for reform within EPRDF and there are also forces opposing the reform. ${ }^{5}$

The other concern of this paper is Ethiopian political culture itself is challenging transitional reform period. After decades of dictatorship, Ethiopians feel they have now been successful and transforming the political culture to real democracy. In Ethiopian previous history, people obey commands from the government because the government uses guns and the coercive power of the state to make them silent. The existing literature argues that in a democratic political culture, citizens obey the government because they respect the rule of law. ${ }^{6}$ But now Ethiopia is at the period where the rule of gun has been defeated and reformist leadership is transforming the political culture of Ethiopia to democracy. However, Ethiopian political culture did not develop the rule of law yet. Therefore, extreme freedom that the new leadership provided to the people is affecting the prevalence of rule of law in Ethiopia.

\footnotetext{
${ }^{1}$ Assefa Fiseha; 'Federalism and Development: The Ethiopian Dilemma' in International Journal on Minority and Group Rights; Volume 5; Issue 3

${ }^{2}$ UN report entitled Ethnic violence triggers crisis in south Ethiopia; July 5, 2018 https:/www.thenational.ae/world/africa/ethnic-violencetriggers-crisis-in-south-ethiopia-1.747553

3 Neamin Ashenafi "The new administration's multifaceted problems The reporter gazzeta7 July 2018 https://www.thereporterethiopia.com/article/new-administrations-multifaceted-problems Vol. XXII No July 7, 2018 Addis Ababa, Ethiopia

${ }^{4}$ Yilikal told to the reporter Gazetta. Yilikal Getnet is a president of the newly established political party called the Ethiopian National Movement (ENM) as cited by Neamin Ashenafi (Ibid)

${ }^{5}$ Leenco Lata, the leader of the Oromo Democratic Front and co-founder of the Oromo Liberation Front. Leenco returned to Ethiopia with other party leaders in May 2018. He made interview with OBN journalist concerning ongoing situation, aired August 04, 2018; 7:00 pm broadcast news

${ }^{6}$ Rachel Kleinfeld, 'Competing Definitions of the Rule of Law'. In Promoting the Rule of Law Abroad. (Ed. T. Carothers ), Carnegie Endowment for International Peace. Washington D.C., 2006.
} 
In all corners, the challenges that are faced by Ethiopian new leadership and transition to democracy raised different questions such as; why such problems occurred at this monumental moment. What are the causes and who is behind these problems? Though these are the general questions shared among many Ethiopians and other scholars the response for such questions remains different. However, unless managed effectively, the existing challenges of transitional reform will bring crisis and may weaken a shift to real democracy. Therefore, the central argument and main objective of this article is to forward possible mechanisms that has to be undertaken in order to address all complex political and social problems and make continue the existing achievements. In so doing, basically this study would address the following questions;

I. What is the existing intuitional capacity in order to maintain peace and security of citizens? Does it require institutional changes? If yes what kind of institution(s) and how to establish or reform the existing?

II. How to reshape the existing ethno-linguistic based federal system that will help to bring national consensus and national unity? What lessons can we draw from the past, almost three decade's experiment of federal system?

III. It is stated somewhere that the foundation for this transitional reform of government in Ethiopia is youth. Therefore, how to make them part and parcel of the reform? What procedures have to be taken in order to make them active participant in governance?

\section{Consolidating Achievements and Making Transition to Democracy}

In Ethiopian existing situation, there are contending views concerning the new leadership effort to transform Ethiopia to democracy and overcome the past almost 150 year's crisis done by preceding regimes. There are groups who oppose ethno-linguistic based federal system itself and describe the need to establish unitary system of governance arguing that ethno-linguistic based federal system is a cause for development of nationalism which may later bring disintegration of the country as a whole. ${ }^{1}$ And others doubt that even Ethiopia will face challenges in the future which would come from two groups. Firstly, those who think that the reform is not going with expected speed and is not bringing a change as it is dreamt and peoples demand. Secondly, the other group whose advantage is hampered because of the reform would not need the reform continuities and they would be other obstacles. ${ }^{2}$ Therefore, this section would provide some highlights of measures that would help Ethiopia to transform to democracy by strengthening achievements made so far.

\subsection{Enforce Strong Rule of Law and Protect Basic Human Rights}

A significant issue that the new government must address is to put into practice the rule of law which would start by bringing criminals who participated in killing of dozens of protesters and top position government officials who were giving direction in old regimes. The new leadership needs to show that it can protect citizen's core rights and establish strong rules of law. By now, ordinary citizens have already seen what happened (anarchism and opportunism) when and where there is no rule of law. The central argument of this paper is that the new leadership should democratize governmental institutions now. If people believe that legal systems and public institutions work for them, rather than against them, it gives them a stake in the system and a greater willingness to tolerate the inevitable turbulence of a transition. The only way to ensure rule of law in this regard is to bring perpetrators of various violence swiftly to justice in order to stem the violence and signal to Ethiopians that the country is changing for good. An effective, transparent, and predictable legal system also prevents wellconnected insiders and those opportunists who want to sabotage the transition.

\subsection{Working with Competitive Political Parties, Elites and Intellectuals of the country}

A part from enforcing strong rule of law for the ongoing reform, the new administration should alerts the mass to have value for democracy and make effective participation in governance and transition to democratization process. Political education at the grass roots level is very crucial to our society through various channels like by creating councils made up of 'Abbaa Gadaas', religious leaders, activists, youth and one or more members from local administrators (This can be customized to local settings) to teach about real ideas and practices in democratic management. In other words include these council as members of local government with greater accountability where government is in close proximity to people.

In order to address and deal with the multifaceted problems of the country, it would be beyond the capability of the EPRDF ruling political party, and therefore this article suggest for the need to establish national political dialogue forum that includes all competitive and opposing political parties including OLF, G-7 and ONLF. The EPRDF's lack of commitment to democracy, as noted, was evidenced by the exclusion of political parties from national dialogue and controlling all seats of house of people representation. In the near future,

\footnotetext{
${ }^{1}$ Ginbot-7, formerly an exiled and armed opposition political party.

${ }^{2}$ The government itself argues that there are forces standing for reform within EPRDF and there are also forces opposing the reform.
} 
Ethiopia is going to undertake a national election after almost one and half years. ${ }^{1}$ One of the most dangerous causes that brought Ethiopia to face protest for the past many years is absence fair and free election. A real democracy is a government in which the supreme power is vested in the people and exercised by them directly or indirectly through a system of representation. An essential element of such a democratic system is free elections. Absent this element, the basis on which the system of elected governance is based deteriorates. The new Ethiopian administration promised that the ultimate goal is to ensure that a democratic election takes place in Ethiopia. ${ }^{2}$ Therefore, unless the new Ethiopian government gives emphasis on the coming election, it would again bring a never ending crisis in Ethiopia.

Empowering political opposition will also contribute to transform Ethiopia to real democracy. The antigovernment protests have shaped serious change and may have the infrastructure to start building healthy opposition parties in the future. However, there are some irresponsible opposition parties that are behaving as if this is just like business as usual. Ethiopia is in a unique and very dangerous, very sensitive situation which requires to move with sensitivity. This paper argues to handle issues and rally in a sensitive and responsible way. Finally, the coming national election to be taken in Ethiopia requires cooperation and working together of both ruling and competitive political parties, if not it would be a mere symbolic and which may become a great challenge of Ethiopian transition to democracy. The opportunity of free, fair and competitive elections in Ethiopia depends on how dedicated the EPRDF may be to dismantling the obstacles it has spent decades building up.

\subsection{Build Unity within Diversity: Learn from the past}

Modern Ethiopia, a multi-ethno linguistic as well as multicultural state not only in eastern Africa but also today's world is created as a result of nation-building and centralization project. The interest of these multi-ethno linguistic societies for accommodation of their diversity was never stopped even though its answer is delayed. It is now almost three decades that Ethiopia established federal system as a way of managing multi ethnolinguistic diversity composed of more than 84 ethnic groups and more than 80 languages with a dozen of cultural systems. $^{3}$

It is now clear that the assimilations assumptions are not valid. It is too much difficult to take Ethiopia back to the era of 'one language and one nation'. The only way out but not option is strengthening the federal system forward. Thus, trying to push back identity politics rather than managing, recognizing the strength of it and providing guarantees against the dreadful side of it, would disintegrate the future of this country. In doing this, managing identity would include but not limited to institutionalization of diversity in Ethiopia. In other words, taming it would be the other mechanism that helps us to build national unity and accommodate diversity because identity politics can be both satisfying and terrifying at the same time. Various researches identified two possible outcomes when leaders of ethnically diverse countries fail to address ethnicity during the transition period. ${ }^{4}$ First, in most African countries including Ethiopia continued suppression of ethnic identities lead to the emergence of open conflict, in which groups demand equal treatment and equal access to development. Second, it was learnt that previous efforts by the state to impose an assimilation policy of a single national identity has been rejected by various groups in the country. Both efforts lead to either failure (in case of assimilation policy) or a bargaining process of multi-ethnic national identity had emerged. In addition, multiethnic societies do not necessarily result in violence or exclusion of conflict, a case in example is that there is a fluid interaction among ethnic groups, through marriage and the marketplace. Hence, it is important to promote ethnic coexistence and a bargaining process would have to recognize differences by striking a balance among groups.

Additionally, the inner view of this paper is that mob justice will take Ethiopia down as state and will bring civil war and collapse which may again require government attention at both policy and institution levels. Educating the mass on democracy and living together is one thing that needs to be executed on daily basis, but making it practical is even a better way of teaching it. Therefore, the government needs to make sure citizens are safe any time, any place while executing their duties and rights. Finally, responsibility and accountability of the justice system is very critical which in this study view is deteriorating.

\subsection{Transform Centralized Federal System to Democratic Federal System}

It is almost three decades since ethno-linguistic federalism is adopted as only option to make Ethiopia survive

\footnotetext{
${ }^{1}$ To hold truly competitive elections in 2020, Ethiopia may need to repeal certain oppressive laws and stop the EPRDF from siphoning off state resources to distribute to its supporters in exchange for power. At the same time, the coalition party must manage hard-liners within the coalition to prevent them from undermining efforts at democracy, as suggested by political scientist Milan Svolik's work on authoritarian governance.

${ }^{2}$ In July, while visiting Washington, Abiy told a group of Ethiopian dissidents that his ultimate goal is to ensure that a democratic election takes place in Ethiopia which was not practical in Ethiopian history.

${ }^{3}$ Ethiopia or officially the Federal Democratic Republic of Ethiopia is the second most populated country in Africa and the characterized by almost more than 80 and 84, ethnic and language groups, respectively. For more detail; World Population Prospects (2017 Revision)

${ }^{4}$ Malory Nye (2007) The Challenges of Multiculturalism, Culture and Religion, 8:2, https://doi.org/10.1080/14755610701458915
} 
from disintegration. However, the past practice of federal system in Ethiopia is characterized by centralized federalism in which the federal government and its institution dominate states government and its institution hindering the constitutionally given states autonomy. Therefore, it is important to maintain the balance of sharedrule and self-rule as one major pillar of democratic federal system otherwise the crisis Ethiopia experienced would come again. A part from this, existing literature suggest that effective decentralization of power to protect local autonomy plays a significant role. This on the other hand requires spreading out the power to local regions that helps to dilute the dangerous unconstitutional concentration of central authority often inherited from authoritarian and previous regimes. It also increases democratic accountability by bringing administration closer to the people. For the past two decades, extreme absence of good governance had been observed that is due to absence of effective devolution of power from the center as the constitution indicates.

The existing literature and various document reports that Indonesia's democracy has benefited from devolution of power ${ }^{1}$. The chaotic political and economic environment of the late 1990s and early 2000s, however, led to grudgingly accept greater devolution as a way of maintaining national unity in the face of growing separatist demands.

Decentralization of power of course by itself alone is not a universal remedy. It requires effective local governance structures and thoughtful decentralization in ways that help deepen and sustain democratization process.

During such transitions from dominant ruling party era to coalition politics of competition, Ethiopia need an independent democratic institutions that serve as shock absorbers during rough ride at this time. They are almost absent and need to be built faster.

In Ethiopian context, something that has not been implemented cannot fail. Ethiopian federal system has been essentially a centralized federal system which is characterized by single party dominance. There are groups, particularly; anti-federalism groups who blame ethnicity have wearing a veil and would disintegrate the state as a whole. Therefore, this paper argues the need to implement ethno-linguistic federal system through empowering the states.

\subsection{Encourage Civil Society Organizations and Empower youth}

The involvement of civil society organizations (CSOs) in public discussion or even policy making is one of the most controversial issues in Ethiopian politics over the last decade. While some would like to see them limited to service delivery, others argue that CSOs could and should indeed have an important role in the political discourse and even policy formulation. ${ }^{3}$ This paper argue that there has to be an event on civil society organization role in consolidating democracy that will bring together distinguished opinion makers, politicians with diverse backgrounds, researchers, advocates as well as the young and the experienced to shed light on important issue. The public must fully participate in the affairs of state, with the state protecting their rights to be recognized. In this context, the value of the role of citizens and civil society is to organize and articulate the interests of local communities. In doing so, various civic societies can play a critical role in this regard in helping citizens discuss about their communities, challenges and opportunities facing their efforts to coexistence.

On the other hand, the owner of this transitional reform is youths. Therefore, they demand to see the fruit of their struggle which could be possible by bringing them to position. A part from this, from this paper point of view a great challenge in the future would be youth unemployment, particularly urban youth. In this context, the new leadership should make it a priority to address this problem and provide support to youth to start small businesses and to youth-led micro- and small-enterprises.

\section{Conclusion}

For the last three years, Ethiopians have been demanding political and economic changes and voicing their frustrations with government policies. The protests resulted the coming to power of new administration though within the same ruling political party, EPRDF. In Ethiopia, the new leadership has accelerated a radical reform programme that is overturning politics in the vast, strategically significant African country. Accordingly, it pledges to build peaceful diplomatic relation with Eretria, to work for inclusive development, compact against corruption and widen the democratic environment in the country.

Though, there are unexpected reforms within this short period of time, there are different challenges, which

${ }^{1}$ EVAN A. Laksmana; 'Is Indonesia Really a Democracy?’ November 10, 2009, 6:00 PM. For more information, see an interview with Rofi Uddarojat at Suarakebebasan.org: http://suarakebebasan.org/en/interview/item/420-rizal-mallarangeng-liberalism-already-won-no-need-forcelebrations

${ }^{2}$ Ibid; PP: 63

${ }^{3}$ Ethiopia cannot reach its full potential without a renegotiation of the relationship between state and civil society. This begins with a clear recognition of the symbiosis between the government and the Ethiopian people. World Bank; 'Civil Society, NGOs and Development in Ethiopia': A Snapshot View; Written by Jeffrey Clark. For more activities and nature of civil society organizations for the past two decades in Ethiopia, refer http://siteresources.worldbank.org/INTRANETSOCIALDEVELOPMENT/8732041111663470099/20489508/CSandDevEthiopiaSnapshotView.pdf 
include the violence in different parts of Ethiopia. It is orchestrated by forces whose goal is to obstruct relative peace and national unity that Ethiopia is witnessing. The central objective of this study was to forward possible mechanisms that help to consolidate achievements and make smooth transition to democracy through overcoming existing challenges.

\section{Acknowledgements}

Many people assisted this work. It would be difficult to list all but I am most grateful for all respondents from political parties both ruling and opposing, academic as well as average citizen who gave me information.

\section{References}

1. Assefa Fiseha (2018); 'Federalism and Development: The Ethiopian Dilemma' in International Journal on Minority and Group Rights; Volume 5; Issue 3; pp 124

2. Evan A. Laksmana; 'Is Indonesia Really a Democracy?' November 10, 2009, 6:00 PM. For more information, see an interview with Rofi Uddarojat at Suarakebebasan.org: http://suarakebebasan.org/en/interview/item/420-rizal-mallarangeng-liberalism-already-won-no-need-forcelebrations

3. IsobeL Coleman, Terra lawson-remer "A User's Guide to Democratic Transitions", A how-to guide for reformers around the world. JUNE 18, 2013, 3:03 PM https://foreignpolicy.com/2013/06/18/a-users-guideto-democratic-transitions/

4. Keller, E., \& M. Omwami, E. Federalism, Citizenship, and National Identity in Ethiopia. The Journal of African Studies, 6(1), 37-69, 2007.

5. Malory Nye (2007) The Challenges of Multiculturalism, Culture and Religion, 8:2, https://doi.org/10.1080/14755610701458915

6. Rachel Kleinfeld, 'Competing Definitions of the Rule of Law'. In Promoting the Rule of Law Abroad. (Ed. T. Carothers), Carnegie Endowment for International Peace. Washington D.C., 2006.

7. Tania F. Cohen How Trump's Claims of a Rigged Election Impact America's Image Abroadhttps://www.huffingtonpost.com/young-professionals-in-foreign-policy/how-trumps-claimsof-a-ri_b_12792726.html

8. World Bank; 'Civil Society, NGOs and Development in Ethiopia': A Snapshot View; Written by Jeffrey Clark.

9. UN report entitled Ethnic violence triggers crisis in south Ethiopia; July 5, 2018 https://www.thenational.ae/world/africa/ethnic-violence-triggers-crisis-in-south-ethiopia-1.747553 